\title{
DETERMINATION OF REACTOGENICITY AND ALLERGENICITY OF THE IMMUNOBIOLOGICAL DRUG FOR PREVENTION AND TREATMENT OF CANDIDIASIS
}

\author{
M.V.Rybalkin, N.I.Filimonova, O.P.Strilets, L.S.Strelnikov \\ National University of Pharmacy \\ Key words: candidiasis; antigen; vaccine; immunity; therapy
}

\begin{abstract}
It is known that the use of drugs, which are capable to stimulate a protective immune response against candidal infection, i.e. immunobiological drugs stimulating protective functions, is a promising direction in the fight against candidiasis. The aim of this work was to study reactogenicity and allergenicity of a new immunobiological drug based on the antigens of $C$. albicans and C. tropicalis fungi. The study of reactogenicity and allergenicity of the solution of the immunobiological drug for prevention and treatment of candidal infection was carried out in healthy guinea pigs weighing 300-400 g; there were 3 animals in the control and experimental groups each. The experimental animals were dehaired on the sides. To determine reactogenicity the solution of the immunobiological drug in the volume of $0.2 \mathrm{ml}$ was injected intradermally on one side of the body. To determine allergenicity the immunobiological drug in the volume of $0.2 \mathrm{ml}$ was injected intradermally to the experimental animals three times at 14 days intervals, and in 14 days after the last injection the immunobiological drug in the volume of $0.2 \mathrm{ml}$ was injected intradermally to guinea pigs. The animals of the control group were injected with the sterile $0.9 \%$ isotonic saline solution. Observations for the presence of local reactions occurrence at the site of injection of the immunobiological drug were performed the first 5 minutes and every 2 hours for 24 hours. As a result of the research conducted it has been found that the immunobiological drug based on the antigens of fungi of C. albicans with the protein concentration of $3 \mathrm{mg} / \mathrm{ml}$ and $C$. tropicalis with the protein concentration of $5 \mathrm{mg} / \mathrm{ml}$ in the ratio of 1:1 for prevention and treatment of candidal infection is not reactogenic and allergenic.
\end{abstract}

Fungi of Candida genus are the most widespread causative agents of fungal infections. They can cause both minor skin lesions and mucous membranes, as well as very serious diseases of almost all organs of the body [1]. Such wide range of infections requires a significant range of diagnostic and therapeutic strategies.

It is known that the use of vaccines for treating candidiasis is considered to be a promising direction. Such studies are carried out actively both on the territory of the former Soviet Union, and in Europe and America $[4,7,8]$. Development of subunit combined vaccines is a priority area $[2,5,6]$. It should be noted that currently no domestic vaccine is produced in Ukraine and no imported vaccines have been registered. Therefore, development of a vaccine against candidiasis is the topical issue of modern pharmacy and medicine.

According to our previous studies the immunobiological drug developed at the National University of Pharmacy and based on the associated antigens of fungi of C. albicans with the protein concentration of $3 \mathrm{mg} / \mathrm{ml}$ and C. tropicalis with the protein concentration of $5 \mathrm{mg} / \mathrm{ml}$ in the ratio of 1:1 is capable of providing the prophylactic and therapeutic effect with two intramuscular injections in the volume of $0.2 \mathrm{ml}[9,10]$.

At the next stage of our research the immunobiological drug developed must be checked on reactogenicity and allergenicity $[3,5,6]$.

The aim of this work is to study reactogenicity and allergenicity of a new immunobiological drug based on the associated antigens of $C$. albicans and C. tropicalis fungi.

\section{Materials and Methods}

The study of reactogenicity of a new immunobiological drug for prevention and treatment of candidal infection was carried out in healthy guinea pigs weighing 300-400 g. There were 3 animals in the control and experimental groups each; they were kept in the same conditions on a standard diet. Before the research the animals acclimatized themselves under experimental room conditions.

The experimental animals were dehaired on the sides, and the solution of the immunobiological drug in the volume of $0.2 \mathrm{ml}$ was injected intradermally on one side of the body. The animals of the control group were injected with the sterile $0.9 \%$ isotonic saline solution. $\mathrm{Ob}$ servations for the presence of local reactions occurrence at the site of injection of the immunobiological drug were performed every 2 hours for 24 hours. In case of the skin redness at the site of injection with the size of more than $5 \mathrm{~mm}$ the drug under study is considered to be reactogenic. The measurement is performed in two perpendicular directions.

The study of allergenicity of the drug was carried out in healthy guinea pigs weighing $300-400 \mathrm{~g}$. There were 3 animals in the control and experimental groups each. The experimental animals were dehaired on the sides and the immunobiological drug in the volume of $0.2 \mathrm{ml}$ was injected intradermally three times at 14 days 
The study of reactogenicity of a new immunobiological drug

\begin{tabular}{|l|c|c|c|}
\hline \multirow{2}{*}{ Groups of animals } & \multicolumn{3}{|c|}{ Animals } \\
\cline { 2 - 4 } & 1 & 2 & 3 \\
\hline Test group & - & - & - \\
\hline Control group & - & - & - \\
\hline
\end{tabular}

Note: «-» - the absence of redness of the skin with the size of $5 \mathrm{~mm}$ and more.

intervals. In 14 days after the last injection the immunobiological drug in the volume of $0.2 \mathrm{ml}$ was injected intradermally to guinea pigs. The animals of the control group were injected with the sterile $0.9 \%$ isotonic saline solution. Sensitizing properties are absent if the body response to the introduction of the drug in guinea pigs is absent, i.e. local reactions, such as redness, are not observed. The body response of the experimental animals was examined in 1-5 min and in 24-48 hours after injection. In case of the skin redness at the site of injection with the size of more than $5 \mathrm{~mm}$ the drug under study is considered to be allergenic. The measurement is performed in two perpendicular directions.

\section{Results and Discussion}

The observation period for the animals was 24 hours. The research results are given in Tab. 1. In the control group of the animals there was a slight redness of the skin when introducing the isotonic saline solution at the site of injection; its sizes did not exceed $3 \mathrm{~mm}$, being a normal skin reaction for the injection.

After introduction of the immunobiological drug to the animals of the test group the skin redness gradually began to appear at the site of injection. The fixed size of the sites with the skin redness in animals did not exceed $3 \mathrm{~mm}$, i.e. research results on reactogenicity were within tolerable limits. Therefore, one may state that the immunobiological drug under study on the basis of the associated antigens of $C$. albicans and C. tropicalis fungi for prevention and treatment of candidal infection is not reactogenic.

The research results on allergenicity showed that there were no local responses at the site of injection in
The study of allergenicity of a new immunobiological drug

\begin{tabular}{|l|c|c|c|}
\hline \multirow{2}{*}{ Groups of animals } & \multicolumn{3}{|c|}{ Animals } \\
\cline { 2 - 4 } & 1 & 2 & 3 \\
\hline Test group & - & - & - \\
\hline Control group & - & - & - \\
\hline
\end{tabular}

Note: «-» - the absence of redness of the skin with the size of $5 \mathrm{~mm}$ and more.

animals of the control group injected with the isotonic saline solution within the first 5 minutes after introduction of the immunobiological drug (Tab. 2). The size of the site with the skin redness in animals did not exceed $3 \mathrm{~mm}$, being a normal skin reaction for the injection. In 24 hours the skin redness in animals almost disappeared at the site of introduction of the immunobiological drug. The research results are given in Tab. 2 .

In the animals of the test group after introduction of the immunobiological drug the size of the skin redness did not also exceed $3 \mathrm{~mm}$ at the site of injection for the first 5 minutes, and in 24 hours the skin redness in animals almost disappeared. Therefore, the research results on allergenicity were within the normal range. It indicates that the immunobiological drug under study on the basis of the antigens of C. albicans and C. tropicalis fungi for prevention and treatment of candidal infection is non-allergenic.

\section{CONCLUSIONS}

1. The immunobiological drug based on the antigens of fungi of $C$. albicans with the protein concentration of $3 \mathrm{mg} / \mathrm{ml}$ and $C$. tropicalis with the protein concentration of $5 \mathrm{mg} / \mathrm{ml}$ in the ratio of 1:1 is not reactogenic.

2 . The immunobiological drug developed for prevention and treatment of candidal infection is non-allergenic.

3. Taking into account the proven action of the immunobiological drug in preventing and treating candidal infection and the data obtained the absence of reactogenic and allergenic properties of this drug is background for creation of an effective and safe medicine.

\section{REFERENCES}

1. Голубка О.В. // Annals of Mechnikov Institute. - 2011. - №2. - C. 51-59.

2. Жукова Н.В., Кривошеева И.М. // Кримський терапевт. журн. - 2013. - №2. - С. 99-104.

3. Краснопольский Ю.М., Борщевская М.И. Фармацевтическая биотехнология. Технология производства иммунобиологических препаратов. - Х.: НТУ «ХПИ», 2009. - 352 c.

4. Пат. 2352355 РФ, МПК А 61 К 39/00, А 61 Р 31/00. - 2007139596/13. Заявл.: 25.10.2007. Опубл.: 25.10.2007.

5. Петров Р.В., Хаитов Р.М. Иммуногены и вакциины нового поколения. - М.: ГЭОТАР-Медицина, 2011. $608 \mathrm{c}$.

6. Семенов Б.Ф., Зверев В.В., Хаитов Р.М. // Журн. микробиол., эпидемиол. и иммунобиол. - 2010. - №2. C. $105-110$.

7. Carvalho A. // Front. Microbiol. - 2012. - Vol. 3. - P. 1-9.

8. Cassone A. // Nature Rev. Microbiol. - 2013. - Vol. 11. - P. 884-891. 
9. Rybalkin M.V., Filimonova N.I., Strilets O.P., Strelnikov L.S. // J. of Chemical and Pharmac. Res. - 2014. - Vol. 6, №4. - P. 954-957.

10. Rybalkin M.V. // Вісник фармаиiї. - 2014. - T. 78, №2. - C. 78-81.

\section{ВИЗНАЧЕННЯ РЕАКТОГЕННОСТІ ТА АЛЕРГЕННОСТІ ІМУНОБІОЛОГІЧНОГО ЛІКАРСЬКОГО ЗАСОБУ ДЛЯ ПОПЕРЕДЖЕННЯ ТА ЛІКУВАННЯ КАНДИДАМІКОЗІВ М.В.Рибалкін, Н.І.Філімонова, О.П.Стрілець, Л.С.Стрельников \\ Ключові слова: кандидамікоз; антиген; вакцина; імунітет; терапія}

Відомо, що використання препаратів, здатних стимулювати захисні імунні реакції проти кандидозної інфекції, тобто імунобіологічні препарати, які стимулюють протективні фрункиії, $є$ перспективним напрямком у боротьбі з кандидозом. Метою даної роботи було дослідження реактогенності та алергенності імунобіологічного лікарського засобу на основі антигенів грибів C. albicans ma C. tropicalis. Дослідження з реактогенності та алергенності розчину імунобіологічного лікарського засобу для попередження та лікування кандидозної інфекції проводили на здорових мурчаках масою 300-400 г по 3 тварини у контрольних та дослідних групах. У дослідних тварин депілювали на боках хутро. Для визначення реактогенності вводили внутрішньошкірно з одного боку тіла розчин імунобіологічного лікарського засобу в об'ємі 0,2 мл. Для визначення алергенності дослідним тваринам вводили внутрішньошкірно трикратно імунобіологічний лікарський засіб у об'ємі 0,2 мл з інтервалом у 14 діб, а через 14 діб після останньої ін'єкції мурчакам уводили внутрішньошкірно імунобіологічний лікарський засіб у об'ємі 0,2 мл. Тваринам контрольної групи вводили фізіологічний розчин. Проводили спостереження за місцем введення імунобіологічного лікарського засобу на наявність виникнення місцевих реакцій у перші 5 хв та через кожні 2 год протягом 24 годин. У результаті проведених досліджень встановлено, що імунобіологічний лікарський засіб на основі антигенів грибів C. albicans з концентрацією білка 3 мг/мл та C. tropicalis з концентрацією білка 5 мг/мл у співвідношенні 1:1 для попередження та лікування кандидозної інфрекції не $є$ реактогенним та алергенним.

\section{ОПРЕДЕЛЕНИЕ РЕАКТОГЕННОСТИ И АЛЛЕРГЕННОСТИ ИММУНОБИОЛОГИЧЕСКОГО ЛЕКАРСТВЕННОГО СРЕДСТВА ДЛЯ ПРЕДУПРЕЖДЕНИЯ И ЛЕЧЕНИЯ КАНДИДАМИКОЗОВ \\ Н.В.Рыбалкин, Н.И.Филимонова, О.П.Стрилец, Л.С.Стрельников}

Ключевые слова: кандидамикоз; антиген; вакцина; иммунитет; терапия

Многие исследователи считают, что использование препаратов, которые способны стимулировать защитные иммунные реакции против кандидозной инфрекции, т.е. иммунобиологические препараты, которые стимулируют протективные фрункции, является перспективным направлением в борьбе с кандидозом. Целью данной работы было исследование реактогенности и аллергенности иммунобиологического лекарственного средства на основе ассоциированных антигенов грибов C. albicans и C. tropicalis. Исследования по реактогенности и аллергенности раствора иммунобиологического лекарственного средства для предупреждения и лечения кандидозной инфрекции проводили на здоровых морских свинках массой 300-400 г по 3 животных в контрольных и опытных группах. В опытных животных депилировали на боках мех. Для определения реактогенности вводили внутрикожно с одной стороны тела раствор иммунобиологического лекарственного средства в объеме 0,2 мл. Для определения аллергенности опытным животным вводили внутрикожно трехкратно иммунобиологическое лекарственное средство в объеме 0,2 мл с интервалом в 14 дней, а через 14 дней после последней инъекции морским свинкам вводили внутрикожно иммунобиологическое лекарственное средство в объеме 0,2 мл. Животным контрольной группы вводили фризиологический раствор. Проводили наблюдение за местом введения иммунобиологического лекарственного средства на наличие возникновения местных реакций в первые 5 мин и через каждые 2 ч в течение 24 часов. Допускается покраснение кожи в месте инъекции на участке не более 5 мм. В результате проведенных исследований установлено, что иммунобиологическое лекарственное средство на основе ассоциированных антигенов грибов C. albicans с концентрацией белка 3 мг/мл и C. tropicalis с концентрацией белка 5 мг/мл в соотношении 1:1 для предупреждения и лечения кандидозной инсрекции не является реактогенным и аллергенным. 